\title{
Analysing narrative genres
}

\author{
Paul Cobley \\ London Guildhall University, \\ 31 Jewry Street, London EC3N 2EY, United Kingdom \\ e-mail: cobley@lgu.ac.uk
}

\begin{abstract}
There can be little doubt that human consciousness is now suffused with narrative. In the West, narrative is the focus of a number of lucrative industries and narratives proliferate as never before. The importance of popular genres in current narrative is an index of the demise of authorship in the face of new media and has necessitated the renewal of the term "genre" in narrative analysis over the last hundred years or so. However, this article attempts to make clear that the concept of genre and the notion of a textual formula in narrative are not the same thing. Genre, in contrast to formula, is concerned precisely with the issue of how audiences receive narrative conventions; however, much genre theory has treated genre as a purely textual entity. The current article argues that genre should properly be considered as an "idea" or an "expectation" harboured by readers and identifies in textualbased genre theory of the last two thousand years the perpetuation of ahistoricality and canonisation.
\end{abstract}

As a term in the analysis of all kinds of narrative discourse - from stories in everyday speech to classical drama, from painting to advertisements - "genre" seems to have been omnipresent. Every consumer of narratives has a rough idea of what "genre" means: a shorthand classification, determining whether a particular text is expected to conform to previous experiences of texts on the part of the consumer. The analysis of genre, however, has tended to treat the concept as an objective entity which can be demonstrated to exist in concrete terms. One reason for this has been the need for analysis to be focused on phenomena which can be shown to be anchored in a text. Yet there are also other reasons for the development of genre's "objective" status which are embedded in the history of the use of the term in theory. 
This essay will consider the use of "genre" and suggest, based on an overview of its past fortunes, an agenda for genre's deployment in a "readerly", multimedia environment of narrative production.

\section{Twentieth century genre theory}

One of the most common observations made about genre theory is that it stayed in a largely steady state for two thousand years after Aristotle's death before accelerating into flux during the twentieth century. Undoubtedly, "genre" in the two millennia before 1900 was a prescriptive device which provided the means for guiding the act of composition or the terms of reference for post hoc evaluation. Yet while genre theory in the twentieth century came to embody new imperatives, it did not totally abandon the prescriptive impulse.

A number of factors muddied the water in twentieth century genre theory. Firstly, narratives proliferated. Whereas Aristotle and his descendants could rely on the fairly limited set of narrative genres denoted by tragedy and comedy in drama, and epic in poetry, print technology in Europe facilitated the growth of the romance and the novel, the latter of which, especially, had already fragmented into a multi-generic entity by the end of the nineteenth century. In the same way that print allowed narrative to spread through multiple copies of printed books, the new media of the twentieth century effected the dissemination of an unprecedented amount of narratives of all sorts. Raymond Williams, writing about dramatic narrative in the 1970s, suggests that

in societies like Britain or the United States more drama is watched in a week or weekend, by the majority of viewers, than would have been watched in a year or in some cases a lifetime in any previous historical period. It is not uncommon for the majority of viewers to see, regularly, as much as two or three hours of drama, of various kinds, every day ... It is clearly one of the unique characteristics of advanced industrial societies that drama as an experience is an intrinsic part of everyday life. (Williams 1974: 59)

On radio, in film, in print, television and cyberspace, narrative genres flourished. Amidst the diversity of narrative over the last hundred years readers might have been in danger of floundering as a result of their inability to choose what narrative is appropriate for them and what offers the potential of enjoyment. 
This signals another way in which genre theory in the twentieth century began to operate in muddy waters. Although it is argued that genre is so intriguing because it has always been a concept "related both to very specialized technical issues and to very broad human ones" (Dubrow 1982: 2), interest in genre has been dramatically bifurcated in recent years. It would be difficult to dispute that theatregoers or the audience for oral storytellers have always been interested to know in advance what type of narrative would be performed for them. Concomitantly, throughout the age of literacy and print, writers and scholars have been only too happy to extol the virtues and enumerate the features of specific genres. Yet, in the twentieth century, the divergence of these ways of knowing about genre became greater as "genre" came to embody both a common sense usage in which moviegoers, novel readers, TV viewers and others saw it as a shorthand for textual classification, and a purely academic usage where theorists searched for textual organization and patterns of (often social) meaning.

Each of these positions in the bifurcation of genre theory have interesting determinants. The academic usage of the term is embedded in the historic development of an analytic mentality in the humanities which is consonant with modernity. This perspective, which, broadly speaking, favours a synchronic investigation of phenomena and a theoretical approach to knowledge over a diachronic and empirical approach, can be seen in the work of Propp and the Formalists in Russia; Ogden, Richards, Empson and Leavis in Britain; the New Criticism, Innis, McLuhan and Frye in North America; the structuralists in France; the Prague Linguistic Circle in Czechoslovakia; and the Copenhagen School in Denmark. The common sense usage of "genre" which developed alongside, but divorced from, twentieth century academic discourse, is determined in a much more nebulous way. On the one hand, its determinants are what Bakhtin calls "primary genres", "certain types of oral dialogue - of the salon, of one's own circle, and other types as well, such as familiar, familyeveryday, sociopolitical, philosophical, and so on" (1986: 65); on the other, its determinants are more akin to "secondary genres", Bakhtin's "literary" or "commentarial" modes, or, more pointedly, the discourses promulgated by the industries responsible for producing narrative genres.

For the humanities in the first two thirds of the twentieth century especially, these latter were problematic. The "mass culture" paradigm posited from opposite ends of the political spectrum (Adorno, Hork- 
heimer 1973; Leavis 1930) found the version of genre offered by the "culture industry" both a curse and a gift. It constituted a curse because, in most cases, academic classifications of texts, particularly popular texts, were compelled to feed off prior classifications made by audiences, the industry responsible for the production of a given text, and the set of discourses associated with the publicity attached to texts (including reviews, interviews, film posters, press releases, publishers' notices, etc). Yet it was a gift because it sometimes seemed that analysis would reveal how debased the genres of mass culture were.

It is true that other possibilities existed deriving from attempts to transcend the stalemate illustrated in my caricature of mass culture theory. Film Noir, for example, is one classification of popular texts which originated in academic circles and was then disseminated through a more popular discourse. A number of American films from the 1940s were taken to constitute a set by post-war French critics. These critics had quite cogent reasons based on textual analysis of style for creating their taxonomy, despite the fact that the original audience for these films, not to mention the industry that created them, had not put this body of films into a generic category (Krutnik 1991: 15). Most frequently, though, academic analysis persevered in its dichotomous separation of all genres. Todorov (1973: 13-14), for example, suggests that a certain number of genres already exist and have existed in the past; but, for him, the role of the academic is also to study the fundamental principles of these, in a similar way to that of Frye (1957) and classical poetics envisioning in the process the possible developments of genres. Thus the normative complexion of genre persisted in the century by means of a generative existence, as a set of conditions to assist in the production of a text but not as conditions which must be met to prevent the text falling outside the genre category.

\section{Genre since the 1970 s}

Major strides in genre theory were made when Anglophone academia began to embrace film as a legitimate object of study. The genre analysis carried out by film theory was initially based on the variable rigour of film critics' observations: the seminal essay on film genre, for example, is often taken to be that of Warshow on the gangster film (Warshow 1962). As film theory matured, however, genre analysis became more circumspect and a fair amount of work published in the 
early 1970s came to have an important influence on contemporary theories of genre. For example, a series of articles appeared in 1970 in the British journal Screen; these interventions, by Ryall, Buscombe and Tudor, along with Kitses' Horizons West (1969), explored some of the key issues still current in genre theory today. These included whether the Western, for example, was constituted by visual elements, or by stock situations, or by plot determinants; whether the industry repeated formulas by audience fiat, and whether "auteurs" were responsible for the construction of meaning in genre films. In a sense, these articles took up Todorov's imperative of theoretically exploring genre, paying close attention to how genre texts function.

By laying out the issue of theoretical genres so baldly, these essays acted as the cue for other genre theorists who took up similar questions of genre in other areas beyond film. Thus, attempts were made to map out the structure of, for example, thrillers (Palmer 1978), Westerns (Wright 1975) and adventure, mystery and melodrama texts (Cawelti 1976). The attention to textual detail and the resolutely synchronic bearing of such genre studies indicates that they are, at least implicitly, indebted to Propp (1968) as well as to Todorov. The English translation of Propp's Morphology of the Folktale had been available since 1958 and appeared in book form ten years later. What Propp lent the genre theorists, in short, was the idea that some texts have a structure that can be repeated time and again with different contents while generally carrying the same meaning. Put another way, genre could be considered an empty vessel, a container into which different contents might be poured. As such, genre was assumed to be objectively "there", a specimen with its own immanent and observable structures. Furthermore, the problem of change regarding the "content" of generic texts seemed to be resolved: that which was objectively "there" carried some meaning that ultimately shaped the "content" no matter what that "content" might be.

Palmer's book on thrillers is probably the clearest example of this belief that the mutability of genres had been resolved. Paramount in his analysis is that genre, in its very organizing principles, carries meaning; and, as with Wright and others, it is argued that that meaning is constant, unchanged by the realm of the extra-textual and unmoved by a text's content. Furthermore, there is excellent reason for such a contention. For Palmer, the genesis of the thriller, the key moment that provides the structure of this particular genre, becomes enshrined in its very principles. In an acute and persuasive analysis, Palmer shows that a set of economic and ideological conditions 
occurring at the moment that the thriller genre crystallized, in the early- to mid-nineteenth century West, resulted in the inscription of capitalist social relations into the genre itself. The fear of crime, the cementing of views about property and theft, coupled with the forging of a liberal hegemony of laissez-faire individualism and entrepreneurial industry all find their generic embodiment in the thriller's hero, his flexible competitive individualism and the threat to the social order from the often "bureaucratic" villain. As such, the genre is constant in its complexion. Indeed, Palmer even refers to the possibility of thrillers with a Trotskyite hero and a multi-national corporation as a villain which, for all their radical rhetoric will remain replays of capitalist social relations simply by virtue of being thrillers (Palmer 1978: 67).

In such a formula, "generic innovation" becomes an oxymoron. The question of the transience of genres, why some genres die out or why certain genres experience revivals remains unanswered (cf. Bennett 1990: 78). This theoretical lacuna constitutes a relatively minor concern, however, in the face of certain dire consequences which can result when such a politically one-sided understanding of genres is espoused. In an essay which continues to be cited and anthologised, Judith Hess Wright offers her own strident interpretation of the "effects" of genre films: "Viewers are encouraged to cease examining themselves and their surroundings, and to take refuge in fantasy from their only real alternative — to rise up against the injustices perpetrated by the present system upon its members" (Hess Wright 1986: 49; anthologised Grant 1995, cited by Neale 2001: 2). The paucity of circumspection in Hess Wright's tone might easily be attributed to the fact that her comments constitute part of an essay which appeared in 1978. However, the passage of twenty years has not been long enough to bury identical sentiments in different quarters: that generic texts have a very limited range of meanings, that the reader can discern only these, that they are meanings which paper over "reality" and, as a consequence, readers (apart from intrepid genre theorists, that is) either believe the unchanging version of the world that generic texts churn out or are distracted from a "proper" perspective on "reality". Here is George Lipsitz, writing in 1998:

Generic conventions encourage the repetition, reconfiguration and renewal of familiar forms in order to cultivate audience investment and engagement. Created mostly for the convenience of marketers anxious to predict exact sales figures by selling familiar products to identifiable audiences, genres also have 
ideological effects. Their conventions contribute to an ahistorical view of the world as always the same; the pleasures of predictability encourage an investment in the status quo. (Lipsitz 1998: 209)

In each case, the simplistic prescriptions made in the service of denouncing generic texts are based on a "monologic" version of genre.

\section{Dialogism and genre}

Although these last examples are extreme versions of the consequences of one perspective on generic texts, they are nevertheless instructive in the way that they highlight the need to think through the dialogical nature of genre at all stages. Those narrative genres which do not die out are not necessarily "fooling the public" every time, nor are they necessarily stale replays of old formulas. Indeed, as Bakhtin (1986: 87) asserts, "speech genres submit fairly easily to reaccentuation, the sad can be made jocular and gay, but as a result something new is achieved (for example, the genre of comical epitaphs)". Re-accentuated genres partake of changed circumstances experienced by the participants in utterances. In a comment which can be found to apply broadly to all narrative genres, Jauss (1982: 79) asserts that "the literary work is conditioned by "alterity", that is, in relation to another, an understanding consciousness". For genre, this reader-orientated perspective is of immense importance.

The work of the Constanz School has made literary theory aware of the way that a given organization of textual elements does not necessarily have sovereignty over a reader's interaction with it. Instead, the reader is at various degrees of liberty to make of texts what $\mathrm{s} / \mathrm{he}$ will, and this includes making texts anew. In fact, following the work of Jauss, Iser and others, academic work on the complexity of the reading process and audience/text relations has flourished in the study of TV, film, written fiction and so on (for example Morley 1980, 1986, 1992; Ang 1984, 1991, 1996; Radway 1984; Seiter et al. 1989; Gray 1992; Liebes, Katz 1993; Lull 1990; Gillespie 1995; Hermes 1996; Nightingale 1996). In general, such work has argued that in order for a text to have any interaction with the reader, considerable creative activity - rather than passivity — on the part of the latter is required. Even where there is an "implied reader", a preferred way of reading a text constructed by intentional inscriptions on the part of the enunciator, the real reader can choose to read differently 
and this "different" reading or construction of meaning will derive from determinants outside texts, including aspects of people's lives (Hermes 2002).

The fact that work on the reading process has been most assiduously pursued in relation to often highly formulaic media texts such as television soap operas or magazines is also crucial for genre theory. Literary-based work on readership has often betrayed its own impetus to valorize literature. Iser's (1974) notion of the "implied reader", for example, is clearly part of a project to delineate "proper" practices of reading as opposed to "aberrant decodings". The same can be said of Eco's (1989) writing on the "open" work or, perhaps to a lesser extent, Barthes' (1978) distinctions in "From work to text". In such cases it is assumed that literary works are, by definition, open to interpretation because they invite a disciplined and skilful reading. Implicitly, generic texts will not be open to interpretation because they invite a form of reading which is, to use Rick Altman's (1987: 4) phrase, "short-circuited". Yet, there is an important distinction here. As soon as the terms of the analysis are shifted to the dialogical relationship of readers and texts, it is difficult to maintain that the seat of genre is purely a textual issue, no matter how much one wishes to distinguish between "literary" and "generic" narratives.

Clearly, all texts carry a multiplicity of meaning or polysemy. A genre text is no different in this respect. It is therefore the potentially wide range of interpretations invited by a genre text of the reader that is short-circuited rather than anything intrinsic to, or immanent in, the text. As Altman is keen to point out, there is a great deal outside the text which determines a genre, such that "genres look different to different audiences" (Altman 1999: 207). For Altman, a cultural commodity such as a genre is "made" through the action of readers who harbour expectations about it. Such expectations are not just created by publicity surrounding a narrative; nor are they, unproblematically, the products of existing belief. Instead, they are the products "also of knowledge, emotions and pleasure" (Jost 1998: 106). Generic meaning is derived partly from competence in reading other narratives in the genre but also from a more diffuse set of knowledges, attitudes, values and experiences brought to the reading of a specific narrative, all of which are in a complex interplay. As such, then, genre is properly an "idea" or an "expectation" harboured by readers.

It is not difficult to see why genre theory has been, until recently, reluctant to make this inevitable move. The unavoidable conclusion 
that genre is a set of expectations rather than a thoroughly textual entity undermines the project of much literary and textual criticism. In a sense, the rise and rise of popular narrative genres in the twentieth century is an index of the demise of authorship and, in a way, this has offered an opportunity to analyse contemporary narrative as if it embodied the return of certain of the principles of pre-literate oral narrative. Following the work of scholars of oral culture such as Lord (2000) and Havelock (1963, 1986), these principles are, in short, that the formulaic quality of narrative has a mnemonic intent and that individual authorship as it is known in literate culture is irrelevant. For genre theorists taking their cue from Propp and Frye, it is axiomatic that formula and repetition in generic narrative are more important than the identification of an individual producer. Yet the analysis of formula in the face of the author's death - or, to put it another way, pace auteurism, the "non-birth" of the author in the generic narratives of film, radio, TV and computers (see Cobley 2001a: 171-200) - is a stop-gap, or even retrograde, measure. The real issue is the reconstitution of genre theory as a feature of the public sphere rather than a textual given.

Is it possible, then, to pursue a theory of genre without the preëminence of the text? The work of Altman, Bennett and others suggests to me that it is and that the outstanding questions in such a reconstituted genre theory concern "reading formations", "verisimilitude", "syntactic/semantic aspects of genre", the "dominant" and the foreshortening of generic production in history.

\section{Reading formations}

Indubitably, the key difficulty that faces the reconceptualized genre theory is that the breadth of any readerly knowledge or "horizon of expectations" is virtually unassimilable in a theoretical discourse. So much so that while various commentators have felt obliged to pay lip service to the issue most have not been able to incorporate it fully in their arguments. Dubrow, for instance, gives just two examples of generic expectations: readers' knowledge of the age and (in consonance with Hirsch 1967) expectations centred on knowledge about the author (Dubrow 1982: 108). Todorov is more reductive still: "Where do genres come from?" he asks; "Quite simply from other genres" (Todorov 1990: 15). For Jauss, on the other hand, the 
horizon of the expectable is constituted for the reader out of a tradition or series of previously known works, and from a specific attitude, mediated by one (or more) genre and dissolved through new works. Just as there is no act of verbal communication that is not related to a generally, socially or situationally conditioned norm or convention, it is also unimaginable that a literary work set itself in an informational vacuum, without indicating a specific situation of understanding. To this extent, every work belongs to a genre - whereby I mean neither more nor less than that for each work a preconstituted horizon of expectations must be ready at hand [...] to orient the reader's (public's) understanding and to enable a qualifying reception. (Jauss 1982: 79)

Jauss, however, is reluctant to venture too far into such a problematic area and, like Dubrow and Todorov, insists on the primacy of aesthetic knowledge in the act of reading, stressing the centrality of taste, subjectivity and perception (Jauss 1982: 23). Broadly, the same can be said of other literary-derived concepts employed to understand readership. Fish's idea of an "interpretive community" (his spelling, see Fish 1980) is more concerned with the forces acting on an audience at the very moment of their interaction with a text rather than with the knowledges, values and experiences which may be at work prior to, and determining, text/reader interactions. Even Altman (1987: 3-5), in his early use of Fish's term in relation to the film musical, is guilty of giving primacy in the production of meanings not to the myriad forces acting on any reader, but to a genre text in its relation to a set of other genre texts.

The work of Tony Bennett (1987, 1990), though, considerably extends the concept of interpretive community by positing instead a space of reading which he calls a "reading formation". He stresses the importance of a number of discursive practices that operate on readers before, and simultaneous with, a textual system, ordering the relations between texts in a definite way "such that their reading is alwaysalready cued in specific directions that are not given by those 'texts themselves' as entities separable from such relations" (Bennett, Woollacott 1987: 64). The reader's knowledge of how texts are organized, and their relations with other texts is largely a knowledge of how various institutions work - the film industry, publishing, broadcasting, advertising. A low level of understanding of relations between these is required for an audience to realize, for example, that an actor is giving an interview on a chat-show at a given moment in time because his/her latest film is currently on general release. Such knowledge, in turn, might be built into a reading of the film. 
At the same time, that which seems wholly untouched by institutional relations is often equally the result of similar determinations. For example, Bennett and Woollacott acknowledge Foucault's insight into the author as "the principle of thrift in the proliferation of meaning" (Foucault 1986: 119), the way that a reader's understanding of authorship might be built into the reading of a text. In their study of the James Bond phenomenon they show that Ian Fleming — the original, but merely one of a number of Bond authors - exists not as a real person but as the nodal point of biographical accounts. They conclude that commentaries have "Bondianised" Fleming's life and thus "Flemingised" Bond as a figure for readers, providing one limit to the polysemous nature of Bond texts (Bennett, Woollacott 1987: 89-90). Moreover, this is subject to change over time: as the output of the present Bond author, Raymond Benson, begins to exceed Fleming's there is even the possibility that some future readers will pay little heed to the biography of Fleming.

This attention to the probabilities of change in considering the longevity of Bond after Fleming suggests that the concept of "reading formation" allows for a consideration of reading relations in different time periods. Strategies of reading the Bond texts in the $1950 \mathrm{~s}$, particularly national ones, are shown by Bennett and Woollacott to be important within the frameworks of other texts. One method of identifying these frameworks is through reviews: the review in the New York Times of the film version of Dr. No, according to Bennett and Woollacott, effectively sold Bond to the American public as a Mickey Spillane character (Bennett, Woollacott 1987: 83). In Britain, however, hard-boiled novels by Spillane and others, while popular in the late 1950s, did not become a point of reference for the reading of the Bond novels but were "eclipsed by the earlier traditions of the "imperialist spy-thriller" which provide by far and away the most influential textual backdrop against which the novels were initially read" (Bennett, Woollacott 1987: 83).

As is evident, then, the concept of reading formation promotes an understanding of reading as an activity which can no longer be considered merely as the realization of textual meanings but is more suitably viewed, instead, as highly determined by ideological and commercial imperatives. Acknowledgement of the work of a reading formation also permits the analyst to consider texts as "texts-inhistory" and "texts-in-use" — that is, as texts that are subject to particular readings rather than as entities with immanent qualities (Bennett 1987). We might tend to commonsensically assume that the 
"meaning" of a text is "in there"; but the interrogation of a reading formation consistently demonstrates that a text's meaning is constantly derived from factors outside of itself (in the past and the present).

In general, the task of a dialogical genre theory will be to establish the determinants of the text-reader relations which accrue to specific genres at specific times. Central to this, then, is the analysis of what readers consider to be decorous, appropriate and feasible in a given genre's representation of the world - that is to say, a genre's verisimilitude.

\section{Verisimilitude}

Todorov (1977) identifies two kinds of norms by which a work or set of statements is said to have verisimilitude: the "rules of the genre" and "public opinion" or doxa. When somebody bursts into song during a musical, this is not, according to the rules of the genre, an indecorous act at odds with the statements in the text: the song is part of a specific regime of verisimilitude and falls within a range of expectations on the part of the audience that such acts are legitimate within the bounds of the genre. Where "public opinion" is concerned, plainly this consists of a set of expectations and understandings of the world by readers rather than the world as a referent. In this way the doxa is a regime of verisimilitude in itself, constantly shifting according to a complex set of checks and balances which characterize the world of discourse in general.

As Todorov (1977: 87) explains, it is more accurate, therefore, to consider verisimilitude as a principle of textual coherence rather than an area in which there exists some relation between the fictional and the real world. What is fundamental to expectations about the thriller genre, for example, is the maintenance of a general level of "credibility" which matches as closely as possible that which is held by the doxa. The thriller is characterized by its attempt to achieve harmony between the consistency of representation within the thriller narrative and what is believed to be credible - politically, socially, topically at a given moment by public opinion. It is for this reason that commentators often make the mistake of believing that thrillers are more "realistic" than other texts or that being "true to life" is a specific and objective expectation harboured by thriller readers (Cobley 1997). 
The specific regime of verisimilitude inherent in particular genres cannot be stressed enough. In romances, the notion of a world beyond or without romantic love is unthinkable in the text-reader interaction. One of the most deft features of Radway's investigation of romance reading, for example, was her request that the group of readers define "failed" or "near-miss" romances. In response, they identified a subgenre which contravened some of their expectations about romance novels but did not totally abandon the belief in romantic love (Radway 1984: 157-185). Similarly, while the thriller genre maintains a specific regime of verisimilitude which gives the genre a close relation to history and non-fiction (Cobley 2000a: 5-14, 34-44) it is flexible in its tutelage and does not police other expectations in order to maintain them as strict rules. The "rules" of detective fiction, for example, were spectacularly contravened in 1926 by Agatha Christie in The Murder of Roger Ackroyd (cf. Dine 1974, Knox 1974); the rules of other genres have undergone similar contraventions (see Tudor 1976: 22 on the Western).

However, while it is true to say that the parameters of generic expectation under the aegis of verisimilitude may be fluid, they are frequently subject to what seem to be two kinds of textual anchoring process.

\section{Semantic/syntactic aspects of genre}

Altman considers two fundamental and inseparable constituents of genre: its "building blocks" and the "structure in which they are arranged". He calls these, respectively, genre's semantic and syntactic aspects (Altman 1986: 30), a distinction which, if as imperfect as it is in linguistics, at least allows for a consideration of print genres' equivalent of filmic iconography. This is to say the semantic dimension does not just consist of the object depicted but includes the methods of realizing the object. In film this will comprise lighting, shots, set design and so on; in writing, this will incorporate all those narrative strategies, such as prose style, which are specific to a text. The syntactic dimension, on the other hand, refers to all those "structural" features identified by previous genre theorists; for example, eventual revelation of the murderer in the "whodunit", a climactic gunfight in the Western, a marriage or consummation of a relationship in the romance. 
It is in the relation of the semantic and the syntactic dimensions that meaning is enacted; but as Altman insists, the semantic and syntactic should not be considered as discrete textual zones. Where genre theorists have defined genre in terms of the semantic realm (textual "contents") or, as is more often the case, its syntactic realm (textual "structure", etc.), Altman suggests that we could more profitably understand reader expectations in terms of an investment in the combined semantic/syntactic realm. As such, the role of the hero in the generic text — which is repeatedly considered a "syntactic" element by theorists after Propp — should not be considered as separable from supposedly "semantic" aspects such as his/her good looks, his/her "goodness" or, if the text is a film, how the hero is shot or positioned in each scene.

Altman's notion of "semantic/syntactic" as combined, it seems to me, pre-supposes the activity of the reader. The semantic/syntactic combination, of course, facilitates short-circuiting by making certain textual features seem naturally inseparable, a clichéd example being, once more, the idea that the "hero" embodies "goodness". But this does not mean that only the producer of a generic text is responsible for its meaning. Altman criticizes Neale and others for their excessive reliance on an understanding of genre expectations as largely created by the film producer's publicity machine and, through an examination of film publicity, argues strongly that producers' discourse contributes surprisingly little to the generic character of films (Altman 1998, 1999). He also criticizes the "conservative" tendencies of theorists such as Hall and de Certeau who implicitly favour a producer-centred understanding of the generation of meaning in their models of "encoding/ decoding" and "poacher/nomad" respectively. Where they see the users of cultural artefacts as interacting with already produced material, Altman exhorts us to explore the use-orientation of readers. As such, there is a need to study the ways in which a cultural commodity such as genre is "made" through the action of readers who harbour expectations. Such expectations are not just created by publicity; nor are they unproblematically the products of existing belief. As we have noted, the reader's knowledge of other texts' semantic/syntactic functioning which s/he recognizes to belong in the same generic system as the text being read represents an important expectation, one which is bound up with questions of pleasures and knowledge. 


\section{The generic dominant}

Following on from these comments on a dialogical genre theory that readers of generic texts operate in a reading formation, that they have expectations of verisimilitude, that they activate already existing knowledges in making sense of textual features in combination - the question no doubt remains as to what makes a generic text different from a non-generic text. The first answer to this question must accord with what has been argued above: the generic character of texts is imputed by a series of extra-textual cues. Yet, in response, it is likely to be asserted that genres still have definable features such as heroes, heroines and outcomes which in some way "dominate" proceedings and have precisely been the object of investigation for textual analysts in the past.

The most systematic formulation of the argument that texts betray a dominant procedure has been offered by work which grew out of Russian Formalism, was taken up by the Prague Linguistic Circle and continued to be a part of Jakobson's theorising (see, for example, Jakobson 1960). Tynjanov's theses on literary evolution survey the issue:

Since a system is not an equal interaction of all elements but places a group of elements in the foreground - 'the dominant' — and thus involves the deformation of the remaining elements, a work enters into the literature and takes on its literary function through this dominant. (Tynjanov 1971: 72)

So, for traditional genre theory, this provides the grounds for understanding any genre consisting of many elements as basically being reducible and subordinate to a dominant procedure, "that which specifically makes it what it is" (Easthope 1983: 24). Hence, Bennett notes, detective fiction is often defined in terms of what Barthes calls the hermeneutic code (Bennett 1990: 99); likewise, Cawelti (1976: especially 42-44) subsumes detective fiction under the procedure of finding out secrets; while Robin Wood, for example, therefore sees the horror film as consisting of one basic formula: "Normality is threatened by the Monster" (Wood 1985: 203).

Yet, as Neale points out

Exclusive definitions, list of exclusive characteristics, are particularly hard to produce. At what point do Westerns become musicals like Oklahoma! (1955) or Paint Your Wagon (1969) or Seven Brides for Seven Brothers (1954)? At what point do Singing Westerns become musicals? At what point do comedies 
with songs (like $A$ Night at the Opera (1935)) become musical comedies. And so on. (Neale 1990: 57)

Like Jameson (1982), Derrida (1981) and others, Neale is emphasizing what users of genre have known for years: that genres are continually overlapping (cf. Neale 2001: 2). But there are two further points to be made in relation to this observation. Firstly, identifying even the intersection of genres is fraught with problems, as evidenced by Neale's own assessment of what constitutes the thriller genre being based, conveniently, on the findings of just two critics (Neale 1990: 66). Secondly, the generic quality of a text will not be based on audience recognition of either a semantic or syntactic dominant but on an investment in the combined semantic/syntactic.

The latter point is made at some length in Radway's now classic study of romance readers. Her group of real readers were very concerned with narrative resolution in their reading matter (Radway 1984: 67) as might be expected in relation to interactions with a genre whose dominant seems to be consummation and a happy ending. Yet real readers cannot be relied upon to read strictly according to a dominant procedure. When considering why they read romances Radway's readers predominantly gave reasons to do with relaxation and social life, but also, and third on the list, "To learn about far away places and times" (Radway 1984: 61). Scientifically inconclusive though this data is, it does indicate that any "syntactic" enjoyment of resolution is also inseparable from the supposedly "non-dominant" semantic elements which, in any narrative, are a necessary part of the movement towards resolution. It is significant, too, that none of the readers chose to articulate their preference for romance reading explicitly in terms of the generic dominant alone. Although audience ethnographies devoted to other genres have not always directly addressed the issue of generic dominants, it is still worth mentioning that Gillespie's (1995) study of Asian residents in the South Eastern British town of Southall reports that soap operas provide an arena for discussing the quality of Punjabi family life, while the respective studies of Dallas audiences by Ang (1986) and by Liebes and Katz (1993) demonstrate that there is no such thing as purely syntactic dominance.

It is possible, as Neale $(1990,2001)$ suggests that the only really demonstrable dominant in the study of narrative genres is narrative itself. Elsewhere, I have argued that as a mode of enunciation, narrative has memorialized and consolidated cultures and that the residue 
of this function can be discerned in all the places where narrative is at play, including journalism, history, medical case histories, and not just fiction (Cobley 2001a). Narrative structure - at its simplest an inexorable movement towards an end which is punctuated by detours - is widespread and pervasive. Yet, in the case of individual genres, the notion of the dominant as a constant defining textual feature is difficult to sustain. So, given that genres should be considered as constituted by the expectations of readers, the only way that a dominant can be properly countenanced is as an element in a reading formation.

This approach seems to characterize contemporary analysis of generic texts. Recent writing on the crime or thriller genre, for example, has tackled the issue of the dominant but has avoided the tendency to treat it as a timeless textual phenomenon which marks genre forever. McCann's analysis of the hard-boiled genre argues that a dramatic crisis and revision of American government during the period of the New Deal effectively heightened the innovation which constituted the new form of writing. By focusing precisely on the "public knowledge and civic solidarity" (McCann 2000: 4) which can be argued to be a dominant of classic detective fiction, the hardboiled, he argues, became "a symbolic theater where the dilemmas of New Deal liberalism could be staged" (McCann 2000: 5). In my own The American Thriller: Generic Innovation and Social Change in the 1970s (Cobley 2000a), I argue that the dominant paranoia and fear of conspiracy in the thriller genre as identified by Palmer (1978), Mandel (1984) and others, is not wholly inevitable at all times but is foregrounded because of the dominance of paranoia and conspiracy fears in that decade's particular reading formation (not coincidentally, the same reading formation in which Palmer and Mandel's analyses appeared). Most persuasive of all, perhaps, is Pepper's (2000) The Contemporary American Crime Novel: Race, Ethnicity, Gender, Class which argues that "strategies of domination do not inevitably reduce subjects or agents to powerless ciphers" and that it is dubious to envisage a dominant procedure providing a vision which characterizes a canon of American crime novels because "the 'best' American crime fiction is messy, disturbing, ambiguous, violent, shocking" (Pepper 2000: 18).

Indeed, it is possible that the notion of a textual dominant, even when merely implicit in genre theories, has been the main cause of a crippling problem in genre analysis which has maintained genre 
theory as one of the last bastions of unthinking ahistoricality. I refer, here, to the issue of generic canons and history.

\section{Generic canons and history}

It is clear that any historian of fictional texts has such an unmanageable wealth of material to wade through that constituting the corpus for study involves, necessarily, not considering a huge number of texts. Hence, one of the most influential histories of the thriller, Julian Symons' Bloody Murder, avoids discussing an "enormous mass of more or less entertaining rubbish" (Symons 1974: 10). This occurs time and time again in the literature of genre criticism with a succession of writers accepting a consensus on a central corpus of texts and their relevance to the history of the genre. The reason for this kind of canon construction is clear. Rather than admitting huge sellers who might have made an impact on public consciousness, historians of genres wish to find some way of dealing with the formidable breadth of the popular fiction industry, to look at "representative" texts and, sometimes, to preserve "value". The principle of critical exclusion, however, tends towards the treatment of the text "as if it were a hermetic and self-sufficient whole, one whose elements constitute a closed system presuming nothing beyond themselves, no other utterances" (Bakhtin 1981: 273). In short, the text is denied its place in history, its coexistence with other generic texts and its existence as the product of contemporary readings.

In any examination of genres in history which is grounded in principles of accuracy rather than evaluation there is a need to gain recognition of the breadth of a particular genre. In histories of the thriller and detective fiction, for example, there has developed a tacit acceptance of an "interregnum", a period in which little or no detective fiction appeared which most critics believe to exist between Wilkie Collins and Arthur Conan Doyle in the nineteenth-century. Yet, as Stewart (1980: 40) argues, this characterization exists only because the precise, dominant, syntactic structure of detective fiction that critics are looking for is not evident at this time. The impulse to canonise according to "good" syntactic structure has the result, therefore, that a huge number of texts which have been popular and important on their own terms are written out of history. As Stewart shows, the texts that appear in the "interregnum" are those that make up the 
popular literature of their age and, although bereft of the "classic" syntax, they do not stand divorced and aloof from the development of detective fiction (cf. Greene 1970, Bleiler 1978). Detective fiction in this period was one part of a more general cultural production which is now becoming an object of academic study in its own right: sensation fiction (Stewart 1980: 76).

The very history of a genre is thus constrained by its textually preconceived basis. More recently, however, writers have almost abolished strict boundaries between genres by concentrating on popular reading as a broad phenomenon. Bloom (1996) and McCracken (1998) interrogate popular texts not so much in terms of specific genres but in terms of affiliations across genres. In their sophisticated analyses there is a notable emphasis on the "pulp mentality" of general popular reading as more than a collection of texts. For them, the way that readers in pulp culture partake of diversity is virtually an emblem of the fragmenting effects of modernity. What their work shows is that we need to be aware of the way in which readers can operate with "nomadic" tendencies (Radway 1988) rather than being confined to one generic preference in a reading formation.

A similar argument has also been put forward in a powerful essay by Gallagher (1986). He contends that, in addition to accounting for the breadth of a genre we need to be sensitive to - rather than patronising about - the historical period in which a generic text appeared. Against the critics who think that the Western film has grown progressively more widespread and sophisticated in its narrative structure he demonstrates that the genre has a much more complicated history. In the period 1907-1915, he shows that there were probably more Westerns released each month than during the entire decade of the 1930s, and as a result, the Western and numerous plots associated with it, were very much in the contemporary cinemagoer's consciousness (Gallagher 1986: 205). Early cinema audiences were not only generically literate, they also inhabited a social formation which, it could be argued, was every bit as complex as our own. For Gallagher, historians of the Western (and, by implication, other genres) tend to ignore the evidence of reading practices in preference for a blanket assumption about the period in which genre texts are located.

I have written about these issues elsewhere in relation to the thriller (Cobley 2000a, 2000b, 2001b) but also in relation to musical genres such as punk rock (Cobley 1999). Indeed, popular music provides a simple example of the problem in question. Older colleagues 
of mine with teenage children express amazement at the breadth of contemporary popular music production which their offspring consume, protesting that a comparable breadth simply did not exist in periods of their own youth such as the 1960s. However, if nothing else, the phenomenon of $\mathrm{CD}$ re-issues and re-mastering in the last decade, a practice which has superseded vinyl deletion, has demonstrated how untrue this perspective is. In genre theory, the issue is simply this: the foreshortening tendency inherent in histories of cultural artefacts carries with it a temptation to deny the breadth of the narrative consumption which has been a constant feature of the cultural landscape of industrial capitalism and mass production. Yet, while this is a difficulty for all histories of cultural artefacts, the problem is particularly acute where genre is concerned. The "short circuiting" process in reading genre can lend itself to a short-circuiting in the analysis of genre. Taking genre as a purely textual phenomenon can foster an understanding of generic texts as formulaic, repetitive, simplistic, unchanging and unproblematically reflective of the ideology of given historical periods rather than, in Bennett's terms, as "texts-in-history"; it also goes hand-in-hand with a view of its readers as naïve, limited, less sophisticated in the past than in the present, and not subject to history.

\section{References}

Adorno, Theodor W.; Horkheimer, Max 1973 [1944]. Dialectic of Enlightenment. London: Allen Lane.

Altman, Rick 1986. A semantic/syntactic approach to film genre. In: Grant, Barry Keith (ed.), Film Genre Reader. Austin: University of Texas Press, 26-40.

- 1987. The American Film Musical. Bloomington: Indiana University Press.

- 1998. Re-usable packaging: Generic products and the recycling process. In: Browne, Nick (ed.), Refiguring American Film Genres: Theory and History. London: University of California Press, 221-232.

- 1999. Film/Genre. London: British Film Institute.

Ang, Ien 1984. Watching Dallas: Soap Opera and the Melodramatic Imagination. London: Routledge.

- 1991. Desperately Seeking the Audience. London: Routledge.

- 1996. Living Room Wars: Rethinking Media Audiences for a Postmodern World. London: Routledge.

Bakhtin, Mikhail M. 1981. The Dialogic Imagination: Four Essays. Holquist, Michael (ed.), trans. Emerson, Caryl; Holquist, Michael. Austin: University of Texas Press. 
— 1986. The problem of speech genres. In: Bakhtin, Mikhail M., Speech Genres and Other Late Essays. Emerson, Caryl; Holquist, Michael (eds.), trans. McGee, V. W. Austin: University of Texas Press.

Barthes, Roland 1978. From work to text. In: Heath, Stephen (ed. and trans.), Image-Music-Text. London: Fontana, 155-164.

Bennett, Tony 1987. Texts, readers, reading formations. In: Attridge, Derek; Bennington, Geoff; Young, Robert (eds.), Post-structuralism and the Question of History. Cambridge: Cambridge University Press, 63-81.

- 1990. Outside Literature. London: Routledge.

Bennett, Tony; Woollacott, Janet 1987. Bond and Beyond: The Political Career of a Popular Hero. London: Macmillan.

Bleiler, Everett Franklin 1978. Introduction. In: Bleiler, Everett Franklin (ed.), Three Victorian Detective Novels. New York: Dover, vii-xvi.

Bloom, Clive 1996. Cult Fiction: Popular Reading and Pulp Theory. London: Macmillan.

Buscombe, Edward 1970. The idea of genre in the American cinema. Screen 11(2): 33-45.

Cawelti, John G. 1976. Adventure, Mystery, and Romance: Formula Stories as Art and Popular Culture. Chicago: University of Chicago Press.

Cobley, Paul 1997. The specific regime of verisimilitude in the thriller. In: Rauch, I. (ed.), Synthesis in Diversity: Proceedings of the 5th Congress of the IASS. Berlin: Mouton, 389-392.

- 1999. Leave the Capitol. In: Sabin, Roger (ed.), Punk Rock: So What? The Cultural Legacy of Punk. London: Routledge, 170-185.

- 2000a. The American Thriller: Generic Innovation and Social Change in the 1970s. London: Palgrave.

- 2000b. The American Thriller: A Text in History. (Thomas A. Sebeok Distinguished Lecture Series.) Toronto: Victoria College, University of Toronto.

- 2001a. Narrative. London: Routledge.

— 2001b. "Who loves ya, baby?" Kojak and the Great Society. In: Gough-Yates, Anna; Osgerby, William (eds.), Tough Guys, Smooth Operators and Foxy Chicks: Analysing the TV Action Series. London: Routledge, 53-68.

Derrida, Jacques 1981. The law of genre. In: Mitchell, W. J. Thomas (ed.), On Narrative. Chicago: University of Chicago Press, 51-77.

Dine, S. S. van 1974. Twenty rules for writing detective stories. In: Haycraft, Howard (ed.), The Art of the Mystery Story. New York: Carroll and Graf [189-193].

Dubrow, Heather 1982. Genre. Methuen: London.

Easthope, Anthony 1983. Poetry as Discourse. London: Methuen.

Eco, Umberto 1989. The Open Work. Trans. Cancogni, A. Cambridge: Harvard University Press.

Fish, Stanley E. 1980. Is there a Text in this Class? The Authority of Interpretive Communities. Cambridge: Harvard University Press.

Foucault, Michel 1986. What is an author? In: Rabinow, Paul (ed.), The Foucault Reader. Harmondsworth: Penguin, 101-120.

Frye, Northrop 1957. The Anatomy of Criticism. Princeton: Princeton University Press. 
Gallagher, Tag 1986. Shoot-out at the genre corral: Patterns in the evolution of the Western. In: Grant, Barry Keith (ed.), Film Genre Reader. Austin: University of Texas Press, 246-260.

Gillespie, Marie 1995. Television, Ethnicity and Cultural Change London: Routledge.

Grant, Barry Keith (ed.) 1995. Film Genre Reader. 2nd ed. Austin: University of Texas Press.

Gray, Ann 1992. Video Playtime: The Gendering of a Leisure Technology. London: Routledge.

Greene, Hugh (ed.) 1970. The Rivals of Sherlock Holmes. Harmondsworth: Penguin.

Havelock, Eric A. 1963. Preface to Plato. Cambridge: Belknap Press.

- 1986. The Muse Learns to Write: Reflection on Orality and Literacy from Antiquity to the Present. New Haven: Yale University Press.

Hermes, Joke 1996. Reading Womens Magazines: An Analysis of Everyday Media Use. Oxford: Polity.

- 2002. The active audience. In: Briggs, Adam; Cobley, Paul (eds.), The Media: An Introduction. 2nd ed. Harlow: Longman.

Hess Wright, Judith 1986. Genre films and the status quo. In: Grant, Barry Keith (ed.), Film Genre Reader. Austin: University of Texas Press, 41-49.

Hirsch, E. Donald jr. 1967. Validity in Interpretation. New Haven: Yale University Press.

Iser, Wolfgang 1974. The Implied Reader: Patterns of Communication in Prose Fiction from Bunyan to Beckett. Baltimore: Johns Hopkins University Press.

Jakobson, Roman 1960. Closing statement: Linguistics and poetics. In: Sebeok, Thomas A. (ed.), Style in Language. Cambridge: Harvard University Press, 350377.

Jameson, Fredric 1982. Towards a new awareness of genre. Science Fiction Studies 28: 322-344.

Jauss, Hans Robert 1982. Toward an Aesthetic of Reception. Minneapolis: University of Minnesota Press.

Jost, François 1998. The promise of genres. Reseaux 6(1): 99-121.

Kitses, Jim 1969. Horizons West. London: Thames and Hudson.

Knox, Ronald A. 1974 [1929, 1946]. Detective story decalogue. In: Haycraft, Howard (ed.), The Art of the Mystery Story. New York: Carroll and Graf, 194-196.

Krutnik, Frank 1991. In a Lonely Street: Film Noir, Genre, Masculinity. London: Routledge.

Leavis, Francis Raymond 1930. Mass Civilization and Minority Culture. London: Heffer.

Liebes, Tamar; Katz, Elihu 1993. The Export of Meaning: Cross-Cultural Readings of Dallas. 2nd ed. Oxford: Polity.

Lipsitz, George 1998. Genre anxiety and racial representation in 1970s cinema. In: Browne, Nick (ed.), Refiguring American Film Genres: Theory and History. London: University of California Press, 208-220.

Lord, Albert 2000. The Singer of Tales. 2nd ed. Mitchell, Stephen; Nagy, Gregory (eds.). Cambridge: Harvard University Press. 
Lull, James 1990. Inside Family Viewing: Ethnographic Research on Televisions Audience. London: Routledge.

Mandel, Ernest 1984. Delightful Murder: A Social History of the Crime Story. London: Pluto.

McCann, Sean 2000. Gumshoe America: Hard-Boiled Crime Fiction and the Rise and Fall of New Deal Liberalism. Durham: Duke University Press.

McCracken, Scott 1998. Pulp: Reading Popular Fiction. Manchester: Manchester University Press.

Morley, David 1980. The Nationwide Audience. London: British Film Institute.

- 1986. Family Television London: Comedia.

- 1992. Television, Audiences and Cultural Studies. London: Routledge.

Neale, Steve 1990. Questions of genre. Screen 31(1): 45-66.

- 2001. Studying genre. In: Creeber, Glen (ed.), The Television Genre Book. London: British Film Institute, 1-3.

Nightingale, Virginia 1996. Studying Audiences: The Shock of the Real. London: Routledge.

Palmer, Jerry 1978. Thrillers: Genesis and Structure of a Popular Genre. London: Edward Arnold.

Pepper, Andrew 2000. The Contemporary American Crime Novel: Race, Ethnicity, Gender and Class. Edinburgh: Edinburgh University Press.

Propp, Vladimir 1968. Morphology of the Folktale. Trans. Scott, Laurence. Austin: University of Texas Press. [Original Russian version: 1928; first English translation 1958.]

Radway, Janice A. 1984. Reading the Romance: Women, Patriarchy and Popular Culture. Chapel Hill and London: University of North Carolina Press.

- 1988. Reception study: Ethnography and the problems of dispersed audiences and nomadic subjects. Cultural Studies 2(3): 359-376.

Ryall, Tom 1970. The notion of genre. Screen 11(2): 22-29.

Seiter, Ellen; Borchers, Hans; Kreutzner, Gabriele; Warth, Eva-Maria (eds.) 1989. Remote Control: Television, Audiences and Cultural Power. London: Routledge.

Stewart, R. F. 1980. ... And Always a Detective: Chapters on the History of Detective Fiction. Newton Abbot: David and Charles.

Symons, Julian 1974 [1972]. Bloody Murder From the Detective Story to the Crime Novel: A History. Harmondsworth: Penguin.

Todorov, Tzvetan 1973. The Fantastic. Ithaca: Cornell University Press.

- 1977. The Poetics of Prose. Ithaca: Cornell University Press.

- 1990. Genres in Discourse. Cambridge: Cambridge University Press.

Tudor, Andrew 1970. Genre: Theory and mispractice in film criticism. Screen 11(6): 33-43.

- 1976. Genre and critical methodology. In: Nichols, Bill (ed.), Movies and Methods, Vol. 1. Berkeley: University of California Press, 118-126.

Tynjanov, Jurij 1971. On literary evolution. In: Matejka, Ladislav; Pomorska, Krystyna (eds.), Readings in Russian Poetics: Formalist and Structuralist Views. Cambridge: MIT Press, 72-74.

Warshow, Robert 1962 [1948]. The gangster as tragic hero. In: The Immediate Experience. Garden City: Doubleday, 127-133. 


\section{Paul Cobley}

Williams, Raymond 1974. Television: Technology and Cultural Form. London: Fontana.

Wood, Robin 1985. An introduction to the American horror film. In: Nichols, Bill (ed.), Movies and Methods, Vol. 2. Berkeley: University of California Press, 195-219.

Wright, Will 1975. Sixguns and Society: A Structural Study of the Western. Berkeley and London: University of California Press.

\section{Анализ нарративных жанров}

Несомненно сознание современного человека погребено под нарративами. На Западе нарратив находится в центре многих прибыльных производств и нарративы распространяются быстрее и шире чем когдалибо раныше. Важность популярных жанров в современном нарративе является знаком смерти автора пред ликом новой медии и привела к необходимости обновления понятия “жанр” в анализе нарратива. Данная статья призвана доказать, что понятия "жанр" и “текстуальное воплощение" не совпадают. В противоположность типу выражения понятие жанра связан с вопросом о том, насколько аудитория принимает нарративные условности. Все же во множестве жанровых теорий жанр рассматривался как чисто текстуальное явление, что привело к узакониванию неисторичности и канонизированности в жанровой теории последних двух тысячелетий, опирающейся на примат текста. Мы считаем, что жанром следует скорее считать читательскую "идею" или "ожидание".

\section{Narratiivsete žanrite analüüs}

Kahtlemata on inimteadvus tänapäeval narratiividega üle ujutatud. Läänes on narratiiv keskmeks hulgale kasumit tootvatele tööstustele ning narratiivid levivad kiiremini ja laialdasemalt kui kunagi varem. Populaarsete žanrite tähtsus tänases narratiivis on märgiks autorluse surmast uue meedia palge ees ning on teinud vajalikuks "žanri" mõiste uuendamise narratiivi analüüsis. See artikkel püüab selgitada, et mõisted žanr ja tekstuaalne väljendusviis ei ole üks ja seesama. Vastupidiselt väljendusviisile puudutab žanr just nimelt küsimust, kuidas auditooriumid narratiivseid konventsioone vastu võtavad; siiski on paljud žanriteooriad käsitlenud žanrit kui puhtalt tekstuaalset entiteeti, mis on viinud ajalootuse ja kanoniseerimise põlistamiseni viimase kahe tuhande aasta tekstipõhises žanriteoorias. Käesolevas artiklis tõendatakse, et žanrit on pigem kohasem pidada lugejates peituvaks "ideeks" või "ootuseks". 